\title{
Effect of Extreme Long-Distance Running on Hepatic Metabolism and Renal Function in Middle-Aged Men
}

\author{
Kyung-A Shin ${ }^{1 *}$ and Young-Joo Kim ${ }^{2, ;, *}$ \\ ${ }^{1}$ Department of Clinical Laboratory Science, Shinsung University, Chungnam 31801, Korea \\ ${ }^{2}$ Department of Exercise Rehabilitaion Welfare, Sungshin University, Seoul 02844, Korea
}

\begin{abstract}
The aim of this study was to investigate the impact of participation in the $622 \mathrm{~km}$ hyper-ultra-marathon on hepatic metabolism and renal function in middle-aged men. Healthy middle-aged male amateur ultra-marathoners between the ages of 40 and 60 . Blood was collected at the pre-race, immediately after $300 \mathrm{~km}, 622 \mathrm{~km}$ hyper-ultra marathon race, 72 hours ( 3 day) and 144 hours (6 day) after the race, AST (aspartate aminotransferase), ALT (alanine aminotransferase), ALP (alkaline phosphatase), $\gamma$-GTP (gamma glutamyl transferase), T-Bil (total bilirubin), D-Bil (direct bilirubin), T-protein (total protein), albumin, uric acid, BUN (blood urea nitrogen), creatinne were analyzed. ALP was significantly increased at $300 \mathrm{~km}, 622 \mathrm{~km}$, day 3 and day 6 than the pre-race. $\gamma$-GTP, T-protein, albumin, uric acid, BUN and creatinine were not significantly different between the distances and the recovery period respectively. AST and ALT were significantly increased at $300 \mathrm{~km}, 622 \mathrm{~km}$, day 3 and day 6 than the pre-race, respectively $(P<0.05)$ at day 3 and day 6 they showed significant decrease from $300 \mathrm{~km}$ and $622 \mathrm{~km}$, respectively $(P<0.05)$. T-Bil and D-Bil increased significantly at $300 \mathrm{~km}$ and $622 \mathrm{~km}$, respectively $(P<.05)$ and significantly decreased at day $3(P<0.05)$ compared to the pre-race, at day 3 and day 6 they were decreased significantly than $300 \mathrm{~km}$ and $622 \mathrm{~km}$, respectively $(P<0.05)$. In conclusion, no disturbance of renal function was observed according to the distances and between the recovery period of $622 \mathrm{~km}$ hyper-ultra marathon race, but reversible hepatocyte function could be degraded and some hemolysis of blood vessels was induced.
\end{abstract}

Key Words: Ultra-marathon, Hepatic metabolism, Renal function

\section{서 론}

울트라 마라톤은 고대 그리스에서 유래된 $42.195 \mathrm{~km}$ (26 miles)의 전통적인 마라톤보다 더 먼 거리를 달리는 스포츠로써 최근 대중화되고 있다(Trappe et al., 2006). 울 트라 마라톤과 같은 극단적인 스포츠는 건강에 부정적 영향을 미쳐 대회가 끝난 후 병원에 입원하거나 사망할 수 있다고 보고된다(Ayus et al., 2000). Mathews 등(2012)은
2000년부터 2009년까지 미국에서 개최된 마라톤 경기에 서 28 명의 사망자가 발생하였다고 보고하고 있다. 따라서 마라톤 보다 더 먼 거리를 달리는 울트라 마라톤 경기시 또는 회복기 동안 주자들의 생리적 변화에 대한 중요성이 강조되고 있다.

과도한 운동은 신체적 손상, 정신적 스트레스 및 산화 적 스트레스, 활성산소(Reactive oxygen species, ROS) 생성 을 초래한다(Leaf et al., 1999; Pedersen and Hoffman-Goetz, 2000; Brancaccio et al., 2007; Agawa et al., 2008; Hattori et al.,

Received: October 1, 2018 / Revised: November 12, 2018 / Accepted: November 13, 2018

*Professor.

${ }^{\dagger}$ Corresponding author: Young-Joo Kim. Department of Exercise Rehabilitaion Welfare Soojung Campus, Sungshin University, 2 Bomun-Ro 34Da-Gil, Seongbuk-Gu, Seoul 02844, Korea.

Tel: +82-2-920-7942, Fax: +82-2-920-7942, e-mail: kyj87@sungshin.ac.kr

(C) The Korean Society for Biomedical Laboratory Sciences. All rights reserved.

(c) This is an Open Access article distributed under the terms of the Creative Commons Attribution Non-Commercial License (http://creativecommons.org/licenses/by-nc/3.0/) which permits unrestricted non-commercial use, distribution, and reproduction in any medium, provided the original work is properly cited. 
2009; Marumoto et al., 2010). 실제로 장거리 달리기는 저나 트륨혈증, 골격근 파괴, 혈장량 변화, 철분결핍, 빈혈, 간손 상 등의 생리학적 변화를 유발한다(Moses, 1990; Smith et al., 2004; Pettersson et al., 2008; Shin et al., 2016). 특히 간 효 소인 LDH (lactate dehydrogenase), AST (aspartate aminotransferase), ALT (alanine aminotransferase), 총 빌리루빈(total bilirubin, T-Bil) 및 ALP (alkaline phosphatase)는 장거리 달리 기에서 상승하며, 상승 정도는 운동량(workload)에 비례 한다(Shin et al., 2016). 또한 신장기능은 BUN (blood urea nitrogen)과 크레아티닌 항목으로 평가할 수 있는데 마라톤 같은 강렬한 운동에서 정상범위 이상 상승하는 것으로 알 려져 있으며(McCullough et al., 2011), 현재까지 마라톤부터 $308 \mathrm{~km}$ 국토횡단 울트라 마라톤에서 이와 같은 지표들의 변화가 조사되었다(Kim et al., 2012; Shin et al., 2016).

극심한 장거리 달리기는 지속적으로 생체 에너지를 소 비하며 극한에 이르는 운동으로 적절한 영양공급과 휴식 을 통해 생리학적 안정성을 회복한 후 경기를 하여야, 손 상을 예방할 뿐만 아니라 적절한 기록을 유지할 수 있다 (Warburton et al., 2002). 그러나 무박 6일을 달려서 150시간 내에 완주해야 하는 $622 \mathrm{~km}$ 울트라 마라톤은 인간 한계에 도전하는 극치의 경기이다. 이 대회를 통한 연구는 현재 까지 이루어지지 않고 있으며 다양한 생리학적 변화에 대 해 조사할 필요가 있다. 따라서 $622 \mathrm{~km}$ 울트라 마라톤이 생화학적 지표 중 간대사와 신장기능에 미치는 영향과 회 복기 반응을 조사하기 위해 $622 \mathrm{~km}$ 울트라 마라톤 경기 전, $300 \mathrm{~km}$ 지점, 종료직후, 회복기 동안(3일, 6 일)의 간대 사와 신장기능 지표 변화를 평가하고자 하였다.

\section{재료 및 방법}

\section{연구 대상자 및 절차}

$622 \mathrm{~km}$ 울트라 마라톤 참가자격은 한반도 횡단대회 $308 \mathrm{~km}$ 를 완주한 자, 제주일주 대회의 $200 \mathrm{~km}$ 를 완주한 자, $622 \mathrm{~km}$ 울트라 마라톤을 중도 포기하였으나 $200 \mathrm{~km}$ 이상을 제한시간 내에 주파한 자, $308 \mathrm{~km}$ 울트라 마라톤을 중도 포기하였으나 $200 \mathrm{~km}$ 이상을 제한시간 내에 주파한 자, 대회일 기준으로 최근 2년 내 대한 울트라 마라톤연맹 에서 공인한 대회에 $200 \mathrm{~km}$ 이상 완주한 자 이어야 한다. $622 \mathrm{~km}$ 울트라 마라톤 주자들은 $50 \mathrm{~km}$ 단위를 제한시간 내에 통과하여야 하며, 통과한 주자는 대회 조직위원, 가 족 및 지인이 준비한 텐트, 음식, 마사지 등을 제공받을 수 있다. 그러나 차량 탑승은 부정행위로 간주하였다. 대
Table 1. Characteristics of demographics fitness in study participants $(n=10)$

\begin{tabular}{lc}
\hline \hline \multicolumn{1}{c}{ Variables } & Mean $\pm \mathrm{SD}$ \\
\hline Age (years) & $52.7 \pm 4.8$ \\
Height $(\mathrm{cm})$ & $171.6 \pm 4.6$ \\
Weight $(\mathrm{kg})$ & $70.5 \pm 5.1$ \\
BMI $\left(\mathrm{kg} / \mathrm{m}^{2}\right)$ & $23.9 \pm 1.6$ \\
Marathon experience (month) & $94.5 \pm 23.1$ \\
Number of participated marathons & $51.12 \pm 54.22$ \\
Race completion time (min) & $8754.0 \pm 152.2$ \\
\hline
\end{tabular}

$\overline{\text { Values are presented as means } \pm \text { standard deviations; BMI, body }}$ mass index

회 1 개월 전 대한 울트라 마라톤연맹 회장에게 실험방법 및 절차에 대해 설명을 한 후 대회 홈페이지에서 인터넷 상으로 지원자를 모집하였다. 참가 의향을 밝힌 자들을 선 별하여 개인 메일로 연구 목적과 절차에 대해 설명하였 으며, 연구동의서를 받은 후 개인적 신상(연령, 신장, 체 중, 운동습관, 개인병력)에 대한 설문지를 받고 연구에 참 여하였다. 본 연구 대상자는 (Table 1)에 나타난 바와 같이 연구에 자발적으로 지원한 40세 이상 60세 이하의 중년 남성으로 선정하였다. 연구 대상자에서 제외되는 기준은 $622 \mathrm{~km}$ 울트라 마라톤 완주에 실패한 자, 경기 규정시간 내에 완주하지 못한 자, 안정시 혈압이 $140 / 90 \mathrm{mmHg}$ 이 상인 자, 협심증이나 심근경색증, 심장수술의 과거력이 있 는 심혈관계 질환자, 당뇨, 신장질환, 간질환자, 고혈압으 로 약물 복용 중인 자는 제외하였다(Fig. 1). $622 \mathrm{~km}$ 울트 라 마라톤은 오전 6시에 시작되었으며, 출발지는 전남해 남 땅끝기념탑에서 도착지는 강원고성 출입국관리소였다. 최저 온도는 $23^{\circ} \mathrm{C}$ 였고 최고 온도는 $32^{\circ} \mathrm{C}$ 이고 상대습도는 $50 \sim 70 \%$ 였다.

\section{혈액채혈}

실험 대상자들은 울트라 마라톤 출발 전, $300 \mathrm{~km}, 622 \mathrm{~km}$ 종료직후, 경기 종료 후 72시간(3 day), 144시간(6 day)에 주 전정맥(antecubital vein)에서 CLSI (Clinical and Laboratory Standards Institute) Guidelines 기준에 따라 채혈을 시행하 였다. 총 단백질, 알부민, AST, ALT, ALP, $\gamma$-GTP (gamma glutamyl transferase), 총 빌리루빈, 직접 빌리루빈(direct bilirubin, D-Bil), BUN, 크레아티닌, 요산은 SST tube (BD Vacutainer Serum Separator Tube, USA)에 채혈 후 3,400 rpm에 서 15 분간 원심분리 후 혈청을 분리하여 $-70^{\circ} \mathrm{C}$ 냉동고에 
보관하였다가 측정하였다. 헤모글로빈과 헤마토크리트는 채혈 후 EDTA (ethylenediaminetetraacetic acid) tube에 담아 즉시 분석하였다.

\section{혈액분석}

생화학검사는 채혈한 혈액의 혈청에서 총 단백질, 알부

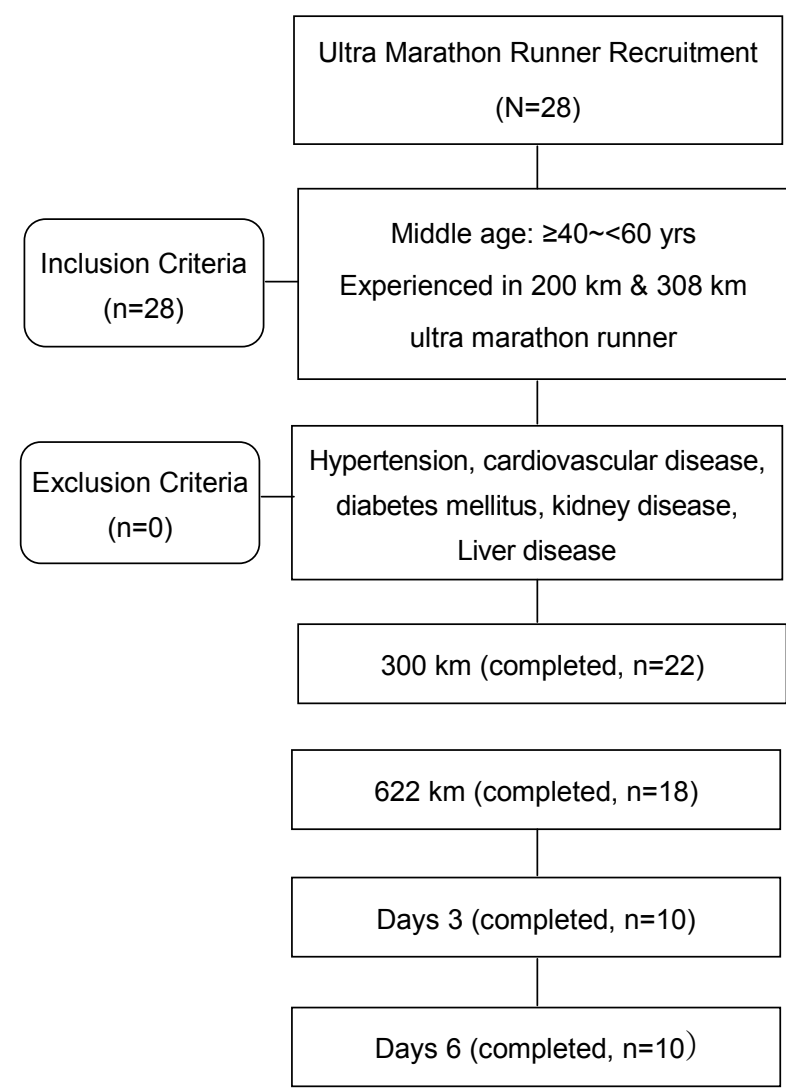

Fig. 1. Flow chart of the study procedure.
민, AST, ALT, $\gamma$-GTP, ALP, 총 빌리루빈, 직접 빌리루빈, BUN, 크레아티닌, 요산은 Denka seiken 시약(Denka seiken Co., Ltd, Japan)을 사용하여 Toshiba TBA-200FR NEO (Toshiba Medical Systems, Japan) 장비로 측정하였다. 각각 의 검사법은 총 단백질은 biuret법, 알부민은 bromcresol green법, AST, ALT는 UV without P5P법, ALP는 PNPP, EAE buffer법, 총 빌루루빈과 직접 빌리루빈은 Jendrassik-Grof법, $\gamma$-GTP는 G-glutamyl-carboxy-nitroanilide (IFCC)법, BUN은 Urease GLDH법, 크레아티닌은 Jaffe법, 요산은 Uricase$\mathrm{POD}$ 법의 원리로 측정하였다. 또한 헤모글로빈과 헤마토 크리트는 Beckman Coulter LH750 (Beckman Coulter, USA) 으로 분석하였다. 혈장량 변화(plasma volume change)는 헤모글로빈과 헤마토크리트치로 산출하였으며, 모든 혈액 검사는 혈장량 변화율로 계산하여 보정하였다(Dill and Costill, 1974).

\section{자료처리방법}

대상자의 개인적인 특성과 혈액지표들은 S-Link statistical package를 이용하여 분석하였으며, 모든 결과는 평균 \pm 표 준편차로 제시하였다. 각각의 구간과 시기간의 차이 검증 은 비모수방법인 일원배치 프리드만(Friedman) 검정을 이 용하였으며, 사후 검정은 윌콕슨(Wilcoxon) 부호순위 검정 을 사용하였다. 차이 검정의 유의수준은 $P<0.05$ 였다.

\section{결 과}

(Table 2)에 나타난 결과에서 ALP는 pre-race (186.7士

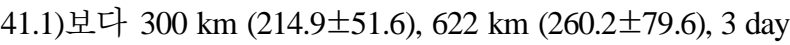
(236.1 \pm 78.2$)$ 그리고 6 day $(206.7 \pm 39.4)$ 에서 각각 유의한 증가를 보였다. 그러나 $\gamma$-GTP, 총 단백질, 알부민, 요산,

Table 2. Change of liver and kidney according to distance and recovery phase in $622 \mathrm{~km}$

\begin{tabular}{lccccc}
\hline \hline \multicolumn{1}{c}{ Factor } & Pre-race & $300 \mathrm{~km}$ & $622 \mathrm{~km}$ & 3 day & 6 day \\
\hline ALP (IU/L) & $186.7 \pm 41.1$ & $214.9 \pm 51.6^{*}$ & $260.2 \pm 79.6^{*}$ & $236.1 \pm 78.2^{*}$ & $206.7 \pm 39.4^{*}$ \\
$\gamma$-GTP (IU/L) & $29.2 \pm 9.7$ & $26.3 \pm 8.6$ & $29.3 \pm 12.8$ & $27.9 \pm 8.5$ & $31.1 \pm 4.9$ \\
T-protein (g/dL) & $7.3 \pm 0.3$ & $8.1 \pm 1.3$ & $8.2 \pm 1.5$ & $7.7 \pm 0.8$ & $7.4 \pm 0.5$ \\
Albumin (g/dL) & $4.5 \pm 0.1$ & $4.3 \pm 0.2$ & $4.3 \pm 0.2$ & $4.4 \pm 0.2$ & $4.4 \pm 0.2$ \\
Uric acid (mg/dL) & $5.9 \pm 1.4$ & $7.2 \pm 2.6$ & $7.0 \pm 2.7$ & $5.5 \pm 1.1$ & $6.5 \pm 1.1$ \\
BUN (mg/dL) & $7.3 \pm 0.3$ & $8.1 \pm 1.3$ & $8.2 \pm 1.5$ & $7.7 \pm 0.8$ & $7.4 \pm 0.5$ \\
Creatinine (mg/dL) & $4.5 \pm 0.1$ & $4.3 \pm 0.1$ & $4.3 \pm 0.2$ & $4.4 \pm 0.2$ & $4.4 \pm 0.2$ \\
\hline
\end{tabular}

Values are presented as means \pm standard deviations; ALP, alkaline phosphatase; $\gamma$-GTP, gamma glutamyl transferase; T-protein, total protein; BUN, blood urea nitrogen; *significantly different from the pre-race at $P<0.05$. 


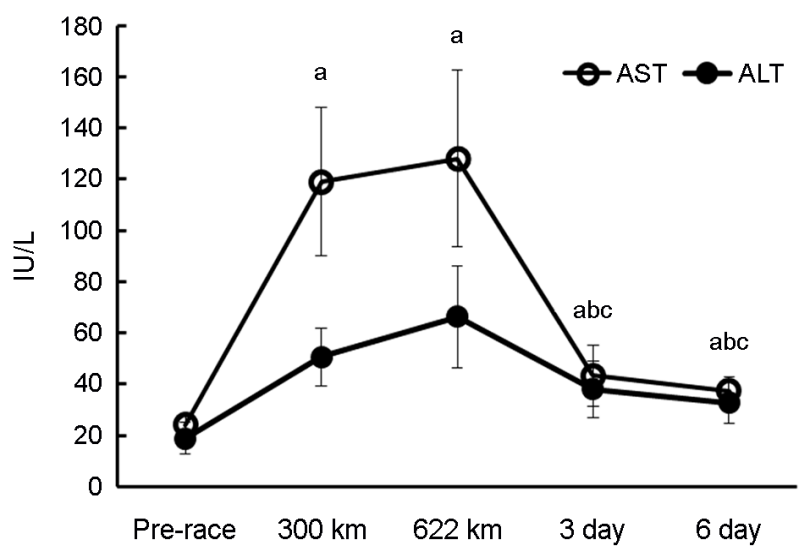

Fig. 2. Changes in AST and ALT according to distance and recovery period in $622 \mathrm{~km}$ Ultra Marathon. AST; aspartate aminotransferase, ALT; alanine aminotransferase. a; Significantly different from the pre-race in AST and ALT at $P<0.05$. b; Significantly different from the $300 \mathrm{~km}$ in AST and ALT at $P<0.05$. c; Significantly different from the $622 \mathrm{~km}$ in AST and ALT at $P<0.05$.

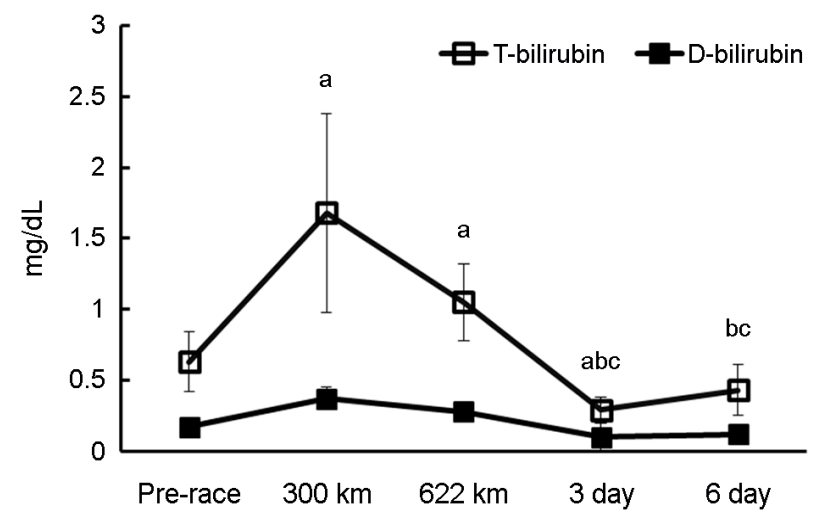

Fig. 3. Changes in T-bilirubin and D-bilirubin according to distance and recovery period in $622 \mathrm{~km}$ ultra marathon. Tbilirubin; total bilirubin, D-bilirubin; direct bilirubin. a; Significantly different from the pre-race in T-bilirubin and D-bilirubin at $P<$ 0.05 . b; Significantly different from the $300 \mathrm{~km}$ in T-bilirubin and D-bilirubin at $P<0.05$. c; Significantly different from the $622 \mathrm{~km}$ in T-bilirubin and D-bilirubin at $P<0.05$.
BUN 그리고 크레아티닌은 각 구간별과 시간별에 유의한 차이가 없었다. (Fig. 2)에 나타난 결과에서 AST는 pre-race (24.2 \pm 3.5$)$ 보다 $300 \mathrm{~km}(118.9 \pm 28.9), 622 \mathrm{~km}(128.0 \pm 34.4)$,

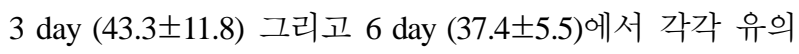
한 증가를 보였으며 $(P<0.05), 3$ day와 6 day는 $300 \mathrm{~km}$ 와 $622 \mathrm{~km}$ 보다 각각 유의하게 감소하였다 $(P<0.05)$. ALT는

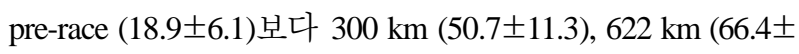
$19.8), 3 \mathrm{~d}$ ay $(38.0 \pm 11.2)$ 그리고 6 day $(32.7 \pm 7.8)$ 에서 각각 유의한 증가를 보였으며 $(P<0.05), 3$ day와 6 day는 $300 \mathrm{~km}$ 와 $622 \mathrm{~km}$ 보다 각각 유의하게 감소하였다 $(P<0.05)$. (Fig. 3)에 나타난 결과에서 총 빌리루빈은 pre-race $(0.63 \pm 0.21)$ 보다 $300 \mathrm{~km}(1.68 \pm 0.7), 622 \mathrm{~km}(1.05 \pm 0.27)$ 에서 각각 유 의한 증가를 보였고 $(P<0.05) 3$ day $(0.29 \pm 0.09)$ 에서 유의 한 감소가 나타났으며 $(P<0.05), 3$ day와 6 day $(0.43 \pm 0.04)$ 는 $300 \mathrm{~km}$ 와 $622 \mathrm{~km}$ 보다 각각 유의한 감소가 나타났다 $(P<0.05)$. 직접 빌리루빈은 pre-race $(0.17 \pm 0.04)$ 보다 $300 \mathrm{~km}$ $(0.37 \pm 0.08), 622 \mathrm{~km}(0.28 \pm 0.04)$ 에서 각각 유의한 증가를 보였고 $(P<0.05), 3$ day $(0.1 \pm 0.1)$ 에서 유의한 감소가 나타났 으며 $(P<0.05), 3$ day와 6 day $(0.18 \pm 0.04)$ 는 $300 \mathrm{~km}$ 와 $622 \mathrm{~km}$ 보다 각각 유의한 감소가 나타났다 $(P<0.05)$.

\section{고 찰}

이 연구는 $622 \mathrm{~km}$ 울트라 마라톤 경기 전후와 회복기간
동안(3일, 6일) 간대사 및 신장기능의 변화와 $622 \mathrm{~km}$ 울트 라 마라톤 후 생리적 회복을 위한 적절한 휴식기간을 알 아보고자 하였다. 그 결과 $622 \mathrm{~km}$ 울트라 마라톤 주자들 에게서 간의 일시적인 기능저하가 나타났으나, 신장기능 에는 변화가 없었다. 또한 저하된 간기능을 회복하기 위 해 최소 6 일 이상의 회복기를 거치는 것이 필요하겠다.

고강도 지구력 운동은 생체 에너지를 지속적으로 소비 시켜 체내 환경이 극한에 이르는 운동이다. 따라서 적절 한 영양공급과 휴식을 통해 체내가 항상성을 회복한 후 경기를 하여야 운동에 의한 손상을 예방할 수 있을 뿐만 아니라 좋은 기록을 얻을 수 있다(Warburton et al., 2002). 마라톤은 근골격계 손상뿐만 아니라 심혈관계, 간, 신장 등에 일시적인 비외상성 손상 및 기능저하를 나타낸다 (Nagel et al., 1990; Kuipers, 1994; Siegel et al., 2001; Kersting et al., 2005; McCullough et al., 2011). 장거리 달리기에서 간 효소인 ALT, ALP, GLDH (glutamate dehydrogenase), $\gamma$-GTP 는 증가하며, 울트라 마라톤에 의한 생리학적 반응은 선 수들의 훈련수준, 운동강도와 지속시간, 운동종류 뿐만 아니라 경기 후 회복기간에 따라 다양한 결과를 보인다 (Nagel et al., 1990; Brancaccio et al., 2006). 이 연구에서 AST 는 경기 전보다 $300 \mathrm{~km}$ 와 $622 \mathrm{~km}$ 에서 각각 4.9 배, 5.3 배 증가하였으며, 회복기 3일에는 URL (upper reference limit) 이상 증가하였고 6 일째에 정상범위로 회복되었다. ALT 는 경기 전보다 $300 \mathrm{~km}$ 와 $622 \mathrm{~km}$ 경기 종료시점에 각각 
2.6배, 3.5 배 증가하였으나, 회복기 3 일에 정상범위로 회복 되었다. 그러나 $\gamma$-GTP는 $622 \mathrm{~km}$ 울트라 마라톤 구간별, 회복기 동안에 차이가 없었다.

울트라 마라톤 경기 중 AST, ALT, $\gamma$-GTP의 활성을 통한 간손상 유무에 대한 평가는 이견이 많다(Fallon et al., 1999). $\mathrm{AST}$ 는 간뿐만 아니라 근육세포에도 존재하며, ALT와 $\gamma$-GTP는 간세포 손상에 더 특이적인 지표이다(Spiropoulos and Trakada, 2003; Skenderi et al., 2006). AST, ALT는 $67 \mathrm{~km}$ (Rehrer et al., 1992), 200 km (Kim et al., 2007), 308 km (Shin et al., 2014) 울트라 마라톤에서 점진적인 증가가 보고되었다. 또한 Nagel 등(1990)은 20 일간의 $1,000 \mathrm{~km}$ 울트라 마라톤 후 간 특이적 효소와 간합성 능력을 평가한 결과 간세포 손상을 보고하였다. 그러나 이러한 효소의 증가는 간세포 손상의 정도를 간접적으로 나타내는 지표이며(Fallon et al., 1999), AST와 ALT의 증가는 장기간 운동에 의한 간의 일 시적인 기능저하를 의미하는 것으로 생각된다(Shin et al., 2014).

$\mathrm{ALP}$ 는 간, 뼈, 소화관에 높은 농도로 존재하는 효소 이며, 운동에 의한 소화관의 허혈성 손상, 뼈의 스트레스 를 반영하는 지표이다(Noakes, 1987; Fallon et al., 1999). 본 연구에서 ALP는 $622 \mathrm{~km}$ 울트라 마라톤 전보다 $300 \mathrm{~km}$, $622 \mathrm{~km}$, 회복기 3일, 6 일째에도 정상범위 내에서 높게 유지 되었으며, ALP를 통해 간손상을 확인하기 위해서는 ALP isoenzymes 측정이 필요할 것으로 생각된다(Fallon et al., 1999). 간의 가장 중요한 기능은 단백질 합성이며, 간세포 손상에 의해 혈장 단백질은 감소한다(Whicher and Spence, 1987). 간의 단백질 합성 능력을 평가하는 두 가지 단백질 로 콜린에스테라아제(cholinesterase)와 혈청 알부민을 들 수 있다(Nagel et al., 1990). 장거리 마라톤에서 콜린에스테 라아제 활성과 혈청 알부민 농도는 감소하였으며, 이는 간에서의 단백질 합성능력 감소와 유산소 기능저하를 나 타내는 결과이다(Nagel et al., 1990; Wu et al., 2004). 또한 24시간 울트라 마라톤 후 총 단백질은 회복기 2일째에 감소하며, 회복기 9일째에도 회복되지 않았다(Wu et al., 2004). 이러한 결과들은 대회 중 음식물 섭취가 불가하거 나 충분히 이루어지지 않았기 때문으로 예상된다. 본 연 구에서는 달리는 중 $50 \mathrm{~km}$ 구간마다 음식과 음료가 충분 히 제공되었기 때문에 총 단백질과 알부민은 $622 \mathrm{~km}$ 울트 라 마라톤에 의해 변화가 없는 것으로 보인다. 따라서 초 장거리 $622 \mathrm{~km}$ 울트라 마라톤 경기 중 혈장 용량도 적절 히 유지되었음을 알 수 있는 결과라 생각된다(Poortmans and Haralambie, 1979).
장거리 경기에서 혈청 빌리루빈 증가는 "foot strike"에 의한 혈관 내 용혈과 관련이 있으며, 적혈구의 근육 내 파 괴와 백혈구 활성에 의한 자유 라디칼(free radicals) 방출에 따른 지질막 과산화작용이 원인이다(Robinson et al., 2006). 또한 용혈은 합토글로빈의 감소, $\mathrm{LDH}$ 의 증가, 적혈구막의 구조적 변화와 관련이 있다(Spitler et al., 1984; Fallon et al., 1999).

본 연구에서 총 빌리루빈은 $300 \mathrm{~km}$ 에서 URL 이상의 상승을 보이다 3 일째에 경기 전 수준으로 회복되었으며, 직접 빌리루빈은 $300 \mathrm{~km}$ 지점에서 최대치를 보이다가 회 복기 3일에 경기 전 수준으로 회복되었다. 운동에 의한 혈 청 빌리루빈 증가는 적혈구 파괴와 헤모글로빈 퇴화에 의 한 것으로 일시적인 혈관 내 용혈은 담즙에서 빌리루빈 배설 증가를 유도한다(Leslie et al., 1985; Deitrick, 1991). 반 면 혈청 빌리루빈의 정상화는 적혈구 재형성의 감소 때문 이며(Wu et al., 2004), 본 연구결과에서는 일시적인 용혈 현상이 회복되는데 3 일의 시간이 요구되었다. 그러나 빌 리루빈의 측정만으로 혈관 내 용혈을 판단하는 데는 어려 움이 있으며, 자유 헤모글로빈(free hemoglobin)의 유출에 의한 헤모글로빈뇨(hemoglobinuria)의 유무, 합토글로빈의 감소가 나타나는지 추가적인 확인이 필요하겠다. 또한 이 전의 연구에서 마라톤 경기를 통해 신장기능의 지표인 혈청 BUN이 증가한다고 보고되었지만(Kratz et al., 2002; Reid et al., 2004) 본 연구결과 혈청 BUN과 크레아티닌은 $622 \mathrm{~km}$ 울트라 마라톤 구간별, 회복기 동안에 유의한 차 이를 보이고 있지 않으므로 신장기능 저하는 발생하지 않 은 것으로 생각된다.

본 연구의 제한점은 $622 \mathrm{~km}$ 울트라 마라톤 후 회복기 동안 대상자의 생활을 동일하게 통제하지 못한 점이다. 또 한 안정시 심박수 및 혈압, 체온, 수면시간, 음주량은 간기 능에 영향을 미칠 수 있음에도 불구하고 본 연구에서 배 제되었으며, 향후 이러한 변인들을 고려한 연구가 추가적 으로 진행되어야 하겠다. 그러나 최근 극한 스포츠에서의 상해 위험과 심각성이 높은 것으로 보고되고 있으나, 역 학적인 연구에 국한되어 있는 실정이다(Caine, 2012). 그러 므로 이 연구는 우리나라에서 시행되는 최장거리 $622 \mathrm{~km}$ 종단 마라톤 후 피로 회복에 따르는 생리적 변화를 생화 학검사를 통해 객관화시켰다는데 의미가 있다. 결론적으 로 $622 \mathrm{~km}$ 울트라 마라톤은 간세포의 기능저하 가능성이 있으며, 일부 혈관 내 용혈을 유발할 가능성이 있다. 


\section{ACKNOWLEDGEMENT}

이 논문은 2017년도 성신여자대학교 학술연구조성비 지원에 의하여 연구되었음.

\section{CONFLICT OF INTEREST}

No potential conflict of interest relevant to this article was reported.

\section{REFERENCES}

Agawa H, Yamada N, Enomoto Y, Suzuki H, Hosono A, Arakawa K, Ghadimi R, Miyata M, Maeda K, Shibata K, Tokudome M, Goto C, Tokudome Y, Hoshino H, Imaeda N, Marumoto M, Suzuki S, Kobayashi M, Tokudome S. Changes of mental stress biomarkers in ultramarathon. Int J Sports Med. 2008. 29: 867-871.

Ayus JC, Varon J, Arieff AI. Hyponatremia, cerebral edema, and noncardiogenic pulmonary edema in marathon runners. Ann Intern Med. 2000. 132: 711-714.

Brancaccio P, Limongelli FM, Maffulli N. Monitoring of serum enzymes in sport. Br J Sports Med. 2006. 40: 96-97.

Brancaccio P, Maffulli N, Limongelli FM. Creatine kinase monitoring in sport medicine. Br Med Bull. 2007. 81-82: 209-230.

Caine DJ. The epidemiology of injury in adventure and extreme sports. Med Sport Sci. 2012. 58: 1-16.

Deitrick RW. Intravascular haemolysis in the recreational runner. Br J Sports Med. 1991. 25: 183-187.

Dill DB, Costill DL. Calculation of percentage changes in volumes of blood, plasma, and red cells in dehydration. J Appl Physiol. 1974. 37: 247-248.

Fallon KE, Sivyer G, Sivyer K, Dare A. The biochemistry of runners in a 1,600 km ultramarathon. Br J Sports Med. 1999. 33: 264 -269 .

Hattori N, Hayashi T, Nakachi K, Ichikawa H, Goto C, Tokudome Y, Kuriki K, Hoshino H, Shibata K, Yamada N, Tokudome M, Suzuki S, Nagaya T, Kobayashi M, Tokudome S. Changes of ROS during a two-day ultra-marathon race. Int J Sports Med. 2009. 30: 426-429.

Kersting UG, Stubendorff JJ, Schmidt MC, Brüggemann GP. Changes in knee cartilage volume and serum COMP concentration after running exercise. Osteoarthritis Cartilage. 2005. 13: 925-934.

Kim HJ, Lee YH, Kim CK. Biomarkers of muscle and cartilage damage and inflammation during a $200 \mathrm{~km}$ run. Eur J Appl
Physiol. 2007. 99: 443-447.

Kim YJ, Lee YH, Shin KA. Effects of amateur marathon races on general hematologic factors. Korean J Sport. 2012. 10: 531 -541 .

Kratz A, Lewandrowski KB, Siegel AJ, Chun KY, Flood JG, Van Cott EM, Lee-Lewandrowski E. Effect of marathon running on hematologic and biochemical laboratory parameters, including cardiac markers. Am J Clin Pathol. 2002. 118: 856-863.

Kuipers H. Exercise-induced muscle damage. Int J Sports Med. 1994. 15: 132-135.

Leaf DA, Kleinman MT, Hamilton M, Deitrick RW. The exerciseinduced oxidative stress paradox: the effects of physical exercise training. Am J Med Sci. 1999. 317: 295-300.

Leslie BR, Sander NW Jr, Gerwin LE. Runner's hemolysis and pigment gallstones. N Engl J Med. 1985. 313: 1230.

Marumoto M, Suzuki S, Hosono A, Arakawa K, Shibata K, Fuku M, Goto C, Tokudome Y, Hoshino H, Imaeda N, Kobayashi M, Yodoi J, Tokudome S. Changes in thioredoxin concentrations: an observation in an ultra-marathon race. Environ Health Prev Med. 2010. 15: 129-134.

Mathews SC, Narotsky DL, Bernholt DL, Vogt M, Hsieh YH, Pronovost PJ, Pham JC. Mortality among marathon runners in the United States, 2000-2009. Am J Sports Med. 2012. 40: $1495-1500$

McCullough PA, Chinnaiyan KM, Gallagher MJ, et al. Changes in renal markers and acute kidney injury after marathon running. Nephrology (Carlton). 2011. 16: 194-199.

Moses FM. The effect of exercise on the gastrointestinal tract. Sports Med. 1990. 9: 159-172.

Nagel D, Seiler D, Franz H, Jung K. Ultra-long-distance running and the liver. Int J Sports Med. 1990. 11: 441-445.

Noakes TD. Effect of exercise on serum enzyme activities in humans. Sports Med. 1987. 4: 245-267.

Pedersen BK, Hoffman-Goetz L. Exercise and the immune system: regulation, integration, and adaptation. Physiol Rev. 2000. 80: 1055-1081.

Pettersson J, Hindorf U, Persson P, Bengtsson T, Malmqvist U, Werkström V, Ekelund M. Muscular exercise can cause highly pathological liver function tests in healthy men. Br J Clin Pharmacol. 2008. 65: 253-259.

Poortmans JR, Haralambie G. Biochemical changes in a 100 km run: proteins in serum and urine. Eur J Appl Physiol Occup Physiol. 1979. 40: 245-254.

Rehrer NJ, Brouns F, Beckers EJ, Frey WO, Villiger B, Riddoch CJ, Menheere PP, Saris WH. Physiological changes and gastro- 
intestinal symptoms as a result of ultra-endurance running. Eur J Appl Physiol Occup Physiol. 1992. 64: 1-8.

Reid SA, Speedy DB, Thompson JM, Noakes TD, Mulligan G, Page T, Campbell RG, Milne C. Study of hematological and biochemical parameters in runners completing a standard marathon. Clin J Sport Med. 2004. 14: 344-353.

Robinson Y, Cristancho E, Böning D. Intravascular hemolysis and mean red blood cell age in athletes. Med Sci Sports Exerc. 2006. 38: 480-483.

Siegel AJ, Lewandrowski EL, Chun KY, Sholar MB, Fischman AJ, Lewandrowski KB. Changes in cardiac markers including B-natriuretic peptide in runners after the Boston marathon. Am J Cardiol. 2001. 88: 920-923.

Shin K, Jee H, Lee Y, Kim TK, Kim HS, Park Y, Kim Y. Effects of an extreme endurance ultra-marathon on musculoskeletal and hematologic functions. Gazzetta Medica Italiana Archivio per le Scienze Mediche. 2014. 173: 283-289.

Shin KA, Park KD, Ahn J, Park Y, Kim YJ. Comparison of Changes in Biochemical Markers for Skeletal Muscles, Hepatic Metabolism, and Renal Function after Three Types of Long-distance Running: Observational Study. Medicine (Baltimore). 2016. 95: e3657.

Skenderi KP, Kavouras SA, Anastasiou CA, Yiannakouris N, Matalas AL. Exertional Rhabdomyolysis during a 246-km continuous running race. Med Sci Sports Exerc. 2006. 38: 1054-1057.

Smith JE, Garbutt G, Lopes P, Tunstall Pedoe D. Effects of prolonged strenuous exercise (marathon running) on biochemical and haematological markers used in the investigation of patients in the emergency department. Br J Sports Med. 2004. 38: 292-294.

Spiropoulos K, Trakada G. Hematologic and biochemical laboratory parameters before and after a marathon race. Lung. 2003. 181: 89-95.

Spitler DL, Alexander WC, Hoffler GW, Doerr DF, Buchanan P. Haptoglobin and serum enzymatic response to maximal exercise in relation to physical fitness. Med Sci Sports Exerc. 1984. 16: 366-370.

Trappe S, Harber M, Creer A, Gallagher P, Slivka D, Minchev K, Whitsett D. Single muscle fiber adaptations with marathon training. J Appl Physiol (1985). 2006. 101: 721-727.

Warburton DE, Welsh RC, Haykowsky MJ, Taylor DA, Humen DP. Biochemical changes as a result of prolonged strenuous exercise. Br J Sports Med. 2002. 36: 301-303.

Whicher JT, Spence CE. Serum protein zone electrophoresis--an outmoded test? Ann Clin Biochem. 1987. 24: 133-139.

Wu HJ, Chen KT, Shee BW, Chang HC, Huang YJ, Yang RS. Effects of $24 \mathrm{~h}$ ultra-marathon on biochemical and hematological parameters. World J Gastroenterol. 2004. 10: 2711-2714.

https://doi.org/10.15616/BSL.2018.24.4.411

Cite this article as: Shin KA, Kim YJ. Effect of Extreme Long-Distance Running on Hepatic Metabolism and Renal Function in Middle-Aged Men. Biomedical Science Letters. 2018. 24: 411-417. 